\title{
Immunoglobulin Heavy Chain Gene Rearrangement in Non B-cell Haematological Malignancies
}

\author{
MN Noor Haslina ${ }^{1}$, R Marini ${ }^{1}$, B Rosnah ${ }^{1}$, MY Shafini ${ }^{1}$, WM Wan Haslindawani ${ }^{1}$, H Mohd Nazri ${ }^{1}$, G Salamah $^{1}$,
} J Hasnan ${ }^{2}$, H Rosline ${ }^{1}$

\begin{abstract}
Purpose: Clonality detection through amplifying immunoglobulin heavy chain (IGH) gene rearrangements by polymerase chain reaction (PCR) is a useful tool in diagnosis of various B-lymphoid malignancies. Immunoglobulin heavy chain gene rearrangement can be an optimal target for clonality detection in B-lymphoid malignancies. In the present study, we evaluated the presence of IGH gene rearrangement in non B-cell haemato-oncology patients including T-cell acute lymphoblastic leukaemia (T-ALL), acute myeloblastic leukaemia (AML) and biphenotypic leukaemia.

Methods: We studied 18 cases of haematological malignancies which comprised five patients with $T$ ALL, 12 patients with AML and one with biphenotypic leukaemia.

Results: We found that the incidence of IGH gene rearrangement in T-ALL and AML were three (60\%) and two (16.7\%), respectively. The patient with biphenotypic leukaemia was negative for IGH gene rearrangement.

Conclusion: Immunoglobulin gene rearrangement, which occurs in almost all haematological malignancies of B-cell lineage, also presents in a very small proportion of T-cell or myeloid malignancies.
\end{abstract}

Keywords: Immunoglobulin heavy chain gene rearrangement, non B-cell haematological malignancy, polymerase chain reaction

\section{Reordenamiento del Gen de la Cadena Pesada de Inmunoglobulina en las Neoplasias Hematológicas de Linfocitos No B}

MN Noor Haslina ${ }^{1}$, R Marini ${ }^{1}$, B Rosnah ${ }^{1}$, MY Shafini ${ }^{1}$, WM Wan Haslindawani ${ }^{1}$, H Mohd Nazri ${ }^{1}$, G Salamah ${ }^{1}$, J Hasnan ${ }^{2}$, H Rosline ${ }^{1}$

\begin{abstract}
RESUMEN
Objetivo: La detección de la clonalidad mediante amplificación de los reordenamientos del gen de la cadena pesada (IGH) de inmunoglobulina por reacción en cadena de la polimerasa (RCP) es una herramienta útil en el diagnóstico de varios tumores malignos linfoides de células $B$. El reordenamiento del gen de la cadena pesada de inmunoglobulina puede ser un objetivo óptimo de la detección de la clonalidad en tumores malignos linfoides de células B. En el presente estudio, se evaluó la presencia de reordenamiento del gen IGH en pacientes de hemato-oncología de células no B, incluyendo la leucemia linfoblástica aguda de células T (LLA-T), leucemia mieloblástica aguda (LMA), y leucemia bifenotípica.

Métodos: Se estudiaron 18 casos de neoplasias malignas hematológicas que abarcaron cinco pacientes con (LLA-T), 12 pacientes con AML y uno con leucemia bifenotípica.

Conclusión: Reordenamiento del gen de la inmunoglobulina que ocurre en casi todas las neoplasias malignas hematológicas del linaje de las células B, también se presenta en una proporción muy pequeña de células To las neoplasias mieloides.
\end{abstract}

From: ${ }^{1}$ Haematology Department and ${ }^{2}$ Pathology Department, Health Campus, Universiti Sains Malaysia, 16150 Kubang Kerian, Kelantan, Malaysia.
Correspondence: Dr MN Noor Haslina, Haematology Department, Health Campus, Universiti Sains Malaysia, Kubang Kerian, Kelantan, Malaysia. E-mail: drhaslina@kb.usm.my 
Palabras claves: Reordenamiento del gen de la cadena pesada de inmunoglobulina, neoplasia hematológica de célula no B, reacción en cadena de la polimerasa

West Indian Med J 2013; 62 (8): 702

\section{INTRODUCTION}

Emanuella et al reported that $10 \%$ of cases of T-cell acute lymphoblastic leukaemia (T-ALL) have rearrangements of the immunoglobulin heavy chain (IGH) gene (1). The association with the T-cell receptor (TCR) phenotype was further supported by the striking relationship between IGH and TCR delta (TCRD) gene rearrangements (2). The study observed the predominance of immature IGH gene rearrangements in immature T-ALL was a result of continuing V(D) J recombinase activity (2).

Gene rearrangement studies on bone marrow cells of patients with acute myeloblastic leukaemia (AML) showed that all cases with gene rearrangements at diagnosis had the same kind of rearrangement at relapse of the disease. Populations with clonal gene rearrangements can be regularly detected at diagnosis, in complete remission and at relapse of AML. Certain gene rearrangements that are detectable at diagnosis have a prognostic significance for the patients' outcome. Gene rearrangement analyses at diagnosis of AML is significant in order to identify poor risk patients (3). The prognostic significance of lymphoid specific genetic markers in AML remains unresolved and should be evaluated further (4).

Different approaches may be chosen to evaluate lymphoid malignancies either at diagnosis or follow-up in light of increasing relevance and proven clinical utility (5). Some of these rearrangements may be detected by polymerase chain reaction (PCR) using VH gene framework III (FRIII) and $\mathrm{JH}$ consensus primers (6). Molecular analysis complements the clinical and histopathologic tools used to diagnose and subclassify haematologic malignancies (7). The generated VHDHJH junction is a successful marker in lymphoproliferative malignancies at initial diagnosis for detection of clonality and during treatment for monitoring minimal residual disease (5).

The PCR is typically used to detect antigen-receptor gene rearrangements as well as specific translocations that can be supplemented by fluorescence in situ hybridization (FISH) and karyotype analysis (7).

\section{SUBJECTS AND METHODS}

This prospective study was conducted at Hospital Universiti Sains Malaysia over a two-year period and was approved by the ethics committee of Universiti Sains Malaysia.

\section{Samples}

We studied cases of non B-cell haematological malignancies which comprised patients with T-ALL, AML and bipheno- typic leukaemia. Bone marrow specimens were used for all cases.

Specimens were obtained from patients in the adult and paediatric haemato-oncology clinic and ward in Hospital Universiti Sains Malaysia. Diagnoses for all cases were based on conventional peripheral blood and bone marrow morphology, cytochemistry and immunophenotyping.

\section{DNA extraction}

Genomic DNA was extracted and purified from peripheral blood using the GENE $\sqrt{ }$ ALL $^{\mathrm{TM}}$ Blood SV mini kit (General Biosystem, Korea) according to the manufacturer's instructions with a slight modification. The concentration of DNA was determined by NanoDrop ${ }^{\circledR}$ Spectrophotometer ND-1000 (NanoDrop Technologies, USA). To perform PCR for the IGH gene rearrangement detection in this study, a concentration of DNA around $200 \mathrm{ng} / \mu \mathrm{l}$ was required. The sample with the higher concentration of the DNA must be diluted to $200 \mathrm{ng} / \mu \mathrm{l}$ prior to use in PCR.

\section{IGH gene detection}

\section{Primers}

Immunoglobulin heavy chain gene rearrangement assay kit from InVivoScribe Technologies, USA, was used. Master mixes were used to test for rearrangement of each targeted gene with each master mixes targeting a different conserved region. Three master mixes included in the IGH gene rearrangement assays target the joining region and all three of the conserved framework regions within the IGH gene. The three master mixes are IGH framework 1 (FR1), IGH framework 2 (FR2) and IGH framework 3 (FR3).

\section{Polymerase chain reaction}

Polymerase chain reaction assays are routinely used for the identification of clonal B-cell populations. These tests amplify the DNA between primers that target the conserved framework (FR) and joining $(\mathrm{J})$ regions. Polymerase chain reaction gene amplification using standard programme for AmpliTaq Gold PCR was performed as recommended by the manufacturer. Thirty-four cycles of amplification were performed using Eppendorf Gradient $\mathrm{S}$ thermocycler (Germany).

The amplified DNA was electrophoresed on a $1.6 \%$ agarose gel in $1 \mathrm{X}$ TBE buffer. DNA was stained using ethidium bromide and visualized under ultra-violet (UV) light. The image was captured using AphaImager electronic imaging system (Alpha Innotech, USA) and archived in the computer for documentation. 


\section{RESULTS}

A total of 18 cases of non B-cell haematological malignancies were included in the study. Five patients were diagnosed with T-ALL, 12 patients with AML and one with biphenotypic leukaemia. Patients with T-ALL ranged in age from 10 to 25 years; AML. Patients were aged from four to 83 years and the biphenotypic patient was 75 years old.

We found that the incidence of IGH gene rearrangement in T-ALL and AML patients was three $(60 \%)$ and two (16.7\%), respectively. The patient with biphenotypic leukaemia was negative for immunoglobulin gene rearrangement.

Two AML patients that were positive for IGH gene rearrangement were diagnosed as AML M2 and AML M3 by FAB classification. Flow cytometry analysis of both cases showed the presence of pan myeloid markers with no lymphoid marker detected. Three patients with diagnoses of TALL were positive for T markers: CD3, CD4, CD5, CD7 and CD8. Only one T-ALL patient that was positive for IGH gene rearrangement showed expression of $\mathrm{T}$ markers with expresssion of CD79a.

\section{DISCUSSION}

We observed that three $(60 \%)$ T-ALL patients were positive for IGH gene rearrangement. A previous study also reported a case of T-cell acute lymphoblastic leukaemia with immunoglobulin kappa light chain gene rearrangement. Griesser reported that clonal IGH gene rearrangement was detected in $20 \%$ of the T-cell lymphomas (8). Yao reported a lower rate of clonal IGH rearrangements in Chinese adult TALL which was only $6 \%$ (9).

All our T-ALL patients with IGH gene rearrangements were CD 3 positive which was in contrast with a previous study that reported that T-ALL with IGH gene rearrangements was found in 19\% of CD3(-) T-ALL (2). The IGH gene rearrangements were observed to be associated with the TCR phenotype which was supported by the striking relationship between IGH and TCR delta gene rearrangements. Another earlier study reported that rearranged IGH genes were detected in $22 \%$ of T-ALL which was associated with involvement of monoallelic and biallelic rearrangements (2).

We observed that $16.7 \%$ of AML patients were having IGH gene rearrangement. Similar results were reported by Schmetzer et al and Boeckx et al, where immunoglobulin gene rearrangements in bone marrow cells of patients with AML was $12 \%$ and $13 \%$, respectively $(3,10)$. Another study reported that IGH genes were rearranged in $39.5 \%$ of AML patients which was higher compared to our study (4). Yen et al reported that clonal IGH gene rearrangement was found in leukaemic cells in $28.2 \%$ of patients (11). A previous study in Japan reported that clonal $\operatorname{IgH}$ gene rearrangement was detected in $40 \%$ of AML patients (12).

Clonally rearranged gene in AML probably represents a bona fide feature of AML and is not very likely to result from amplification of minor clones or non-clonal reactive cells. There was no association detected between IGH monoclonality and specific cytogenetic abnormalities or immunophenotypic pattern (4). The prognostic significance of clonal antigen receptor gene rearrangement in AML remains unresolved. Remission and relapse incidence or duration of remission was not found to be affected by monoclonally rearranged IGH genes (4). A previous study found that IgG was expressed at a high frequency and level in AML cell lines and primary myeloblasts, but not in monocytes or neutrophils from patients with non-haematopoietic neoplasms or healthy controls (13).

The AML patients who were positive for IGH gene rearrangements showed no lymphoid markers expression. This is in contrast with the findings by Boeckx et al who observed that the frequency of IGH gene rearrangements was higher in patients with expression of B-cell associated markers [CD19 and/or CD20] (10). Patients with AML with rearranged IGH also showed significantly lower expression levels of RAG1 and RAG2 (10). Acute myeloblastic leukaemia-derived $\operatorname{IgG}$ may be a novel AML-related gene that contributes to leukaemogenesis and AML progression (13).

Another study in Japan observed that overall survival of immunoglobulin heavy chain-polymerase chain reaction (IgH-PCR) positive and negative patients at 25 months was 29 and $88 \%$, respectively. Immunoglobulin heavy chainpolymerase chain reaction positivity may be a poor prognostic factor in AML (12). However, the study by Yen et al reported that clonal rearrangements of IgH genes found in AML patients did not appear to affect the prognosis (11). Acute myeloblastic leukaemia-derived IgG may serve as a useful molecular marker for monitoring minimal residual disease or designing target therapy (13).

We observed that no IGH gene rearrangement was detected in the biphenotypic patient in our study who expressed panmyeloid markers together with $\mathrm{cCD} 3, \mathrm{CD} 5$, CD7, CD34 and CD38. No B-cell associated marker was expressed. Boeckx et al observed a significant association between the expression of B-cell associated markers (CD19 and/or CD20) and the presence of Ig gene rearrangements (10). Zuchini et al reported an uncommon case of biphenotypic acute leukaemia in which leukaemic blasts expressed myeloid antigens and cyCD79a molecule. Gene rearrangement analysis of the IGH and T-cell-gamma chain (TCRgamma) receptor showed a germline configuration of the TCR and clonal rearrangement of IGH genes (14). Golomivic et al reported that IGH gene rearrangements correlated well with lymphoid biphenotypic acute leukaemia morpholology (15).

\section{CONCLUSION}

Immunoglobulin heavy chain gene rearrangement occurs in a very small proportion of T-cell or myeloid malignancies.

Its influence on the diagnostics of morphologically unclear cases in particular is crucial and is useful in establish- 
ing a diagnosis in specimens in which morphological and immunophenotypic studies are inconclusive.

\section{ACKNOWLEDGEMENT}

This work was supported by a USM short term grant 304/PPSP/6131492. We thank the members of molecular laboratory (Department of Haematology), Puan Narishah, Puan Salwana and Puan Salamah Shukri for helpful discussions and technical support.

\section{REFERENCE}

1. Pilozzi E, Muller-Hermelink HK, Falini B, de Wolf-Peeters C, Fidler C, Gatter K et al. Gene rearrangements in T-cell lymphoblastic lymphoma. J Pathol 1999; 188: 267-70.

2. Szczepanski T P-WM, langerak AW, Harts WA, Wijkhuijs AJ, van Wering ER, van Dongen JJ. Ig heavy chain gene rearrangements in Tcell acute lymphoblastic leukemia exhibit predominant DH6-19 and DH7-27 gene usage, can result in complete V-D-J rearrangements, and are rare in T-cell receptor alpha beta lineage. Blood 1999; 93: 4079-85.

3. Schmetzer HM, Braun S, Wiesner D, Duell T, Gerhartz HH, Mittermueller J. Gene rearrangements in bone marrow cells of patients with acute myelogenous leukemia. Acta Haematol 2000; 103: 125-34.

4. Stavroyianni N, Belessi C, Stamatopoulos K, Kosmas C, Paterakis G, Abazis D et al. Expression of recombination activating genes-1 and-2 immunoglobulin heavy chain gene rearrangements in acute myeloid leukemia: evaluation of biological and clinical significance in a series of 76 uniformly treated patients and review of the literature. Haematologica 2003; 88: $268-74$.

5. Gleissner B, Thiel E. Detection of immunoglobulin heavy chain gene rearrangements in hematologic malignancies. Expert Rev Mol Diagn 2001; 1: 191-200.
6. Height SE, Swansbury GJ, Matutes E, Treleaven JG, Catovsky D, Dyer MJ. Analysis of clonal rearrangements of the Ig heavy chain locus in acute leukemia. Blood 1996; 87: 5242-50.

7. Sholl LM, Longtine J. Molecular analysis of genetic markers for nonHodgkin lymphomas. Curr Protoc Hum Genet 2010; Chapter 10: Unit 10.14.1-25. doi: 10.1002/0471142905.hg1014s65.

8. Griesser DH. [Analyses of the rearrangement of T-cell receptor- and immunoglobulin genes in the diagnosis of lymphoproliferative disorders]. Veroff Pathol 1995; 144: 1-109.

9. Yao L. The pattern of clonal immunoglobulin and T-cell receptor (Ig/TCR) gene rearrangements in Chinese adult acute lymphoblastic leukemia patients. Leuk Res 2008; 32: 1735-40.

10. Boeckx N, Willemse MJ, Szczepanski T, van der Velden VH, Langerak AW, Vandekerckhove $\mathrm{P}$ et al. Fusion gene transcripts and Ig/TCR gene rearrangements are complementary but infrequent targets for PCRbased detection of minimal residual disease in acute myeloid leukemia. Leukemia 2002; 16: 368-75.

11. Yen CC, Liu JH, Wang WS, Chiou TJ, Fan FS, Chen PM. Prognostic significance of immunoglobulin and $\mathrm{T}$ cell receptor gene rearrangements in patients with acute myeloid leukemia: Taiwan experience. Leuk Lymphoma 1999; 35: 179-87.

12. Kyoda K, Nakamura S, Matano S, Ohtake S, Matsuda T. Prognostic significance of immunoglobulin heavy chain gene rearrangement in patients with acute myelogenous leukemia. Leukemia 1997; 11: 803-6.

13. Qiu X, Sun X, He Z, Huang J, Hu F, Chen L et al. Immunoglobulin gamma heavy chain gene with somatic hypermutation is frequently expressed in acute myeloid leukemia. Leukaemia 2013; 27: 92-9.

14. Zucchini A, Fattori PP, Lanza F, Ferrari L, Bagli L, Imola M et al. Biphenotypic acute leukemia: a case report. J Biol Regul Homeost Agents 2004; 18: 387-91.

15. Golemovic M, Sucic M, Zadro R, Mrsic S, Mikulic M, Labar B et al. IgH and TCRgamma gene rearrangements, cyclin A1 and HOXA9 gene expression in biphenotypic acute leukemias. Leuk Res 2006; 30: $211-21$ 